\title{
Geothermics of the Pannonian basin and its bearing on the neotectonics
}

\author{
L. Lenkey ${ }^{1}$, P. Dövényi ${ }^{1}$, F. Horváth ${ }^{1}$, and S. A. P. L. Cloetingh ${ }^{2}$ \\ ${ }^{1}$ Department of Geophysics, Eötvös University, Pázmány Péter sétány 1/c, 1117 Budapest, Hungary \\ ${ }^{2}$ Institute for Earth Sciences, Vrije Universiteit, De Boelelaan 1085, 1081 HV Amsterdam, The Netherlands
}

Received: 13 November 2000 - Accepted: 1 May 2002

\begin{abstract}
Different aspects of the geothermics of the Pannonian basin are investigated from the viewpoint of neotectonics. A heat flow map of the basin and the surrounding region is presented. It is shown that the high heat flow of the Pannonian basin, the subsidence and maturation history of the Neogene sediments can be explained in general by Middle Miocene extension and thinning of the lithosphere. To obtain fit to the observed vitrinite reflectance data in the peripheral areas uplift and erosion had to be assumed, which started in the Late Pliocene. For the same time period a thermo-mechanical extensional model would predict thermal subsidence, therefore, the observation of this late stage uplift suggests that the thermal subsidence has been overprinted by tectonic forces, like an increase of intraplate stress.

Groundwater flow in porous sedimentary rocks or in fractured rocks disturbs the geothermal field making difficult the interpretation of the heat flow in terms of simple conductive models. However, from the viewpoint of tectonics the occurrence of thermal springs is helpful, because most of the thermal springs occur along faults. Almost half of the thermal springs in Hungary are found along faults, which have been active during the Late Pliocene through Quaternary period.

The relationship between the geothermics and the seismicity of the Pannonian basin has also been investigated. It is shown that the seismicity can be understood in terms of collision of the Adriatic microplate with Europe and differences in thermal state of the lithosphere. The tectonically less active Bohemian Massif, Ukrainian and Moesian Platforms form a cold rigid frame of the Pannonian basin. The Pannonian basin and the Dinarides comprise a complex seismotectonic unit. The Pannonian basin, which is characterized by high heat flow, has low to moderate seismic activity, with earthquakes occurring in the upper crust. The Dinarides, which are characterized by low heat flow, have high seismic activity and the focal depth of the earthquakes reaches $40 \mathrm{~km}$. Rheological profiles constructed for the region show that in the Pannonian basin only the upper 10-14 km thick
\end{abstract}

Correspondence to: L. Lenkey (lenl@freemail.hu) part of the crust has brittle strength, as opposed to the Dinarides where the brittle part of the crust is $20-24 \mathrm{~km}$ thick, and there is a mechanically strong layer also in the upper mantle.

\section{Introduction}

The terrestrial heat flow provides basic information on the geothermal processes at depth. There are abundant temperature and thermal conductivity measurements in the Pannonian basin and the surrounding region, which allow the determination of the heat flow in many locations (Čermák, 1978; Demetrescu, 1978; Dövényi et al., 1983; Dövényi and Horváth, 1988; Ravnik et al., 1995). One of the aims of this paper is to present an updated heat flow map of the Eastern Alps-Carpathians-Pannonian basin-Dinaric region.

After correcting for the thermal effects of paleoclimatic changes, sedimentation, erosion and groundwater flow, the heat flow is generally interpreted in the framework of geodynamic models (Chapman and Rybach, 1985; Mongelli et al., 1989). The high heat flow in the Pannonian basin is explained by Middle Miocene extension and thinning of the lithosphere (e.g. Royden et al., 1983), which is evidenced by the presence of thin crust (Mituch and Posgay, 1972; Posgay et al., 1991; Horváth, 1993), thin lithosphere (Babuška and Plomerová, 1988; Praus et al., 1990; Horváth, 1993) and normal faults in the basement of Neogene sediments (e.g. Tari et al., 1992). It is shown in this paper that the subsidence, thermal and maturation history of the basin can be fairly well explained in terms of non-uniform extension of the lithosphere, but the recent uplift of the peripheral parts of the basin requires additional tectonic forces. It has been suggested (Horváth and Cloetingh, 1996) that late-stage (Late Pliocene and Quaternary) uplift observed in the Pannonian basin is controlled by an increase of intraplate stress.

The distribution of seismicity is, in many cases, controlled by temperature (Furlong and Atkinson, 1993; Bodri and Iizuka, 1993), although exceptions are known to occur. The areal distribution of seismicity and heat flow in the 
Pannonian basin and the surrounding region is investigated. The connection between temperature and seismicity is established through rock mechanics. Sibson (1982) suggested that the base of the seismogenic layer in continents is given by the depth of the transition from dominantly brittle to dominantly ductile strain accommodation. Rheological profiles are constructed for the Pannonian basin and the surrounding region and they are compared to the variation of the focal depths of earthquakes.

\section{Heat flow in the Pannonian basin and surrounding ar- eas}

In order to know the features of the geothermal field heat flow density determinations have to be carried out. The terrestrial heat flow density (shortly heat flow) is defined as the product of the vertical temperature gradient and the thermal conductivity assuming conductive heat transfer. Heat flow determinations in the Pannonian basin were made in deep boreholes. Mercury maximum thermometers or thermistor probes were used to determine the vertical temperature gradient. The paleoclimatic and topographic effects were not considered, because the temperature measurements were made at great depths, (greater than $500 \mathrm{~m}$, mostly in the depth range of 1000-2000 m), where the paleoclimatic and topographic influences are negligible. Thermal conductivities of rocks were measured on core samples in laboratory. Based on the results Dövényi and Horváth (1988) established thermal conductivity-depth trends for the Neogene and Quaternary sand-sandstones and shales-clays-marls in the Pannonian basin. Using the thermal conductivity-depth trends and the thermal conductivities of other rocks derived also from laboratory measurements (Dövényi et al., 1983) heat flow was calculated in many boreholes, where the lithology of the borehole was known and reliable temperature data were available. The temperature database of Hungary contains more than 12000 data from 4600 boreholes. The temperature data come from bottom hole temperatures, inflowing and outflowing water temperatures, drill-stem tests in hydrocarbon exploration wells and some steady-state temperature measurements. Those temperature data were used in the heat flow calculation, which could be corrected for the thermal disturbance of drilling. Heat flow was calculated following the thermal resistance integral procedure of Bullard (1939). The error of heat flow determinations is $\pm 10-25 \%$ in favourable and nonfavourable cases, respectively.

The observed heat flow is often disturbed by sedimentation, erosion and groundwater flow. The average thickness of Neogene and Quaternary sediments in the Pannonian basin is $2-3 \mathrm{~km}$, but in the deep troughs the thickness of sediments reaches $7-8 \mathrm{~km}$. The thermal effect of sedimentation was calculated by a one-dimensional numerical model following the method of Lucazeau and Le Douaran (1985), which takes into account the variation in the sedimentation rate and the change in the thermal properties of sediments due to compaction (Lenkey, 1999). The heat flow corrected for sedi- mentation is $10-30 \%$ higher than the observed heat flow. The late stage (0-5 Ma) erosion of the peripheral and some internal parts of the basin has insignificant effect on the heat flow $\left(\sim 5 \mathrm{~mW} / \mathrm{m}^{2}\right)$.

The heat flow corrected for sedimentation is shown in Fig. 1. The map in Hungary is based on 28 heat flow determinations (thermal conductivity and temperature measurements were carried out in the same borehole) and approximately 1500 heat flow estimates (thermal conductivity is estimated from the lithology using the thermal conductivitydepth trends) (Dövényi, 1994). Outside Hungary the map is based on the "Geothermal Atlas of Europe" (Hurtig et al., 1992). The isolines of the heat flow map of Europe from the atlas were digitized outside Hungary, and these data together with the Hungarian data were used to construct the heat flow map of Fig. 1. The new heat flow data from Hungary in the border zone were in good agreement with the existing data from the surrounding areas, and the above method ensured the smooth transition of isolines between the two areas. Data coverage is quite good for the whole area except the Apuseni Mountains and the Eastern Alps, where only few measurements were made. Outside the Carpathians the thermal effect of sedimentation has not been corrected.

The surface heat flow distribution in the Pannonian basin shows values ranging from 50 to $130 \mathrm{~mW} / \mathrm{m}^{2}$, with a mean value of $100 \mathrm{~mW} / \mathrm{m}^{2}$. The average heat flow in the basin is considerably higher than in the surrounding regions. The Ukrainian and Moesian Platforms are characterized by low heat flow values of $40-50 \mathrm{~mW} / \mathrm{m}^{2}$, which are typical for the stable continental crust (Demetrescu et al., 1989; Gordienko et al., 2001). The Carpathians and the Bohemian Massif show varying heat flow values of $50-70 \mathrm{~mW} / \mathrm{m}^{2}$, which are close to the worldwide mean value for continental crust $\left(65 \mathrm{~mW} / \mathrm{m}^{2}\right.$, Pollack et al., 1993). The Outer Dinarides are characterized by extremely low heat flow values $\left(<30 \mathrm{~mW} / \mathrm{m}^{2}\right)$. The low heat flow is due to karstic water flow in the carbonatic rocks of the mountains (Ravnik et al., 1995). The Inner Dinarides have heat flow of $50-60 \mathrm{~mW} / \mathrm{m}^{2}$. The Adriatic Sea shows varying heat flow of $30-50 \mathrm{~mW} / \mathrm{m}^{2}$. The high heat flow in the Eastern Alps is based on a few and unreliable data. The peripheral Vienna and Transylvanian basins are characterized by lower heat flow values $\left(50-70 \mathrm{~mW} / \mathrm{m}^{2}\right.$ and $50 \mathrm{~mW} / \mathrm{m}^{2}$, respectively) than the central basins. The low heat flow in the Transylvanian basin suggest that it was formed by a different geodynamic mechanism than the Pannonian basin (Kázmér et al., 2000).

The central areas exhibit varying heat flow. The hottest areas are the southern, eastern (Great Hungarian Plain) and northeastern parts (East Slovakian basin) of the basin where the heat flow is above $100 \mathrm{~mW} / \mathrm{m}^{2}$. The $\mathrm{NW}$ part of the Pannonian basin is characterized by heat flow values of 80 $90 \mathrm{~mW} / \mathrm{m}^{2}$, which are lower than the mean value. The heat flow maxima $\left(>130 \mathrm{~mW} / \mathrm{m}^{2}\right)$ is found in the south. The NNW-SSE directed heat flow maxima south to the Pannonian basin (until the Vardar zone) has no proven geodynamic explanation.

The high heat flow in the southern part of the Eastern 


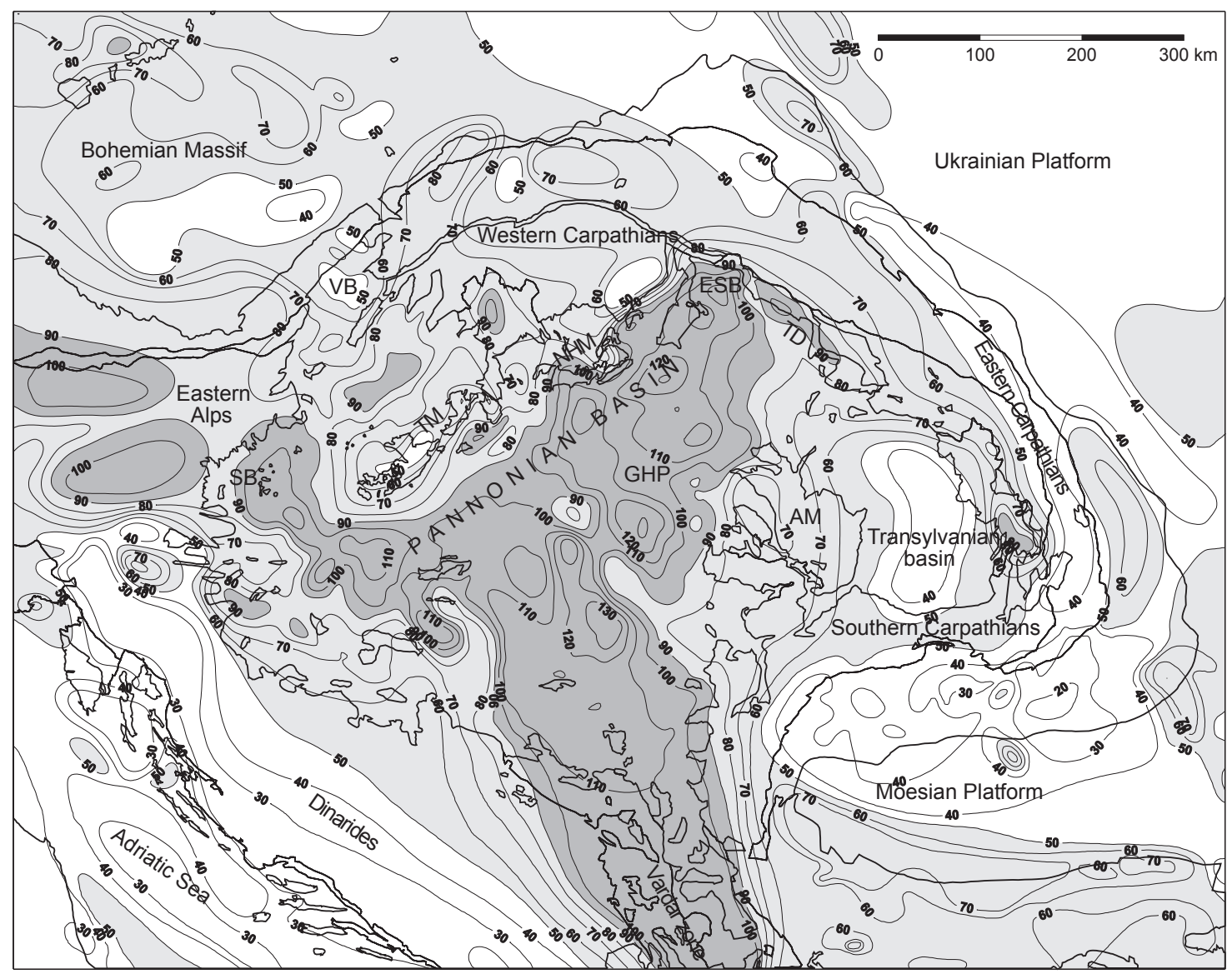

Fig. 1. Heat flow in the Pannonian basin and the surrounding areas. Inside the basin the heat flow is corrected for the Neogene sedimentation. Contour interval is $10 \mathrm{~mW} / \mathrm{m}^{2}$. Thick lines denote the boundaries of the Carpathian molasse and flysch belts, the outcrop of the pre-Neogene rocks and Neogene volcanic rocks on the surface. VB: Vienna basin, SB: Styrian basin, TM: Transdanubian Mountains, NHM: North Hungarian Mountains, GHP: Great Hungarian Plain, ESB: East Slovakian basin, TD: Transcarpathian depression, AM: Apuseni Mountains.

Carpathians is caused by volcanism, which ceased $0.2 \mathrm{Ma}$ ago (Pécskay et al., 1995). Calculations of the thermal evolution of volcanic intrusions show that the elevated temperature and heat flow around an intrusion dissipates in a few million years (e.g. Fowler and Nisbet, 1982; Horváth et al., 1986). Thus, the thermal anomaly caused by the Middle Miocene calc-alkaline volcanism and along the inner side of the Carpathian arc has decayed by now. However, the heat flow is still high along the volcanic chain. The high heat flow cannot be explained by the increased radioactive heat production in the volcanic rocks, because the concentration of the radioactive isotopes is normal (Surányi et al., 2002). The high heat flow must have a deeper (lower crustal or mantle) origin. The source of the heat is probably related to the cause of the volcanism. The Pliocene to Pleistocene basaltic magmatism was sporadic and the basalts appear as small volcanic cones or dykes. Due to their small volume their thermal effect was not significant.

The Transdanubian Mountains and some parts of the North Hungarian Mountains (Bükk, Aggtelek-Gemer Karst, for location see Fig. 2) are characterized by low heat flow (50$60 \mathrm{~mW} / \mathrm{m}^{2}$ ). These mountains are built up from Mesozoic carbonates, which outcrop to the surface. The fractured and karstified rocks have large permeability, which allows easy infiltration of the precipitation. The downgoing water cools almost the whole area of the outcrops. The water is heated up at depth and returns to the surface at the feet of the mountains in thermal springs. The heated areas are restricted to the narrow paths, where the water emerges. The depth of water penetration can be estimated from the temperature of the springs. Assuming that the thermal conductivity of carbonates is $3 \mathrm{Wm}^{-1}{ }^{\circ} \mathrm{C}^{-1}$ and the heat flow is $60 \mathrm{~mW} / \mathrm{m}^{2}$, the resulting geothermal gradient is $20^{\circ} \mathrm{C} / \mathrm{km}$. To obtain a water temperature of $30^{\circ} \mathrm{C}$ in case of an infiltration temperature of $10^{\circ} \mathrm{C}$ the water has to descend at least $1 \mathrm{~km}$ depth. The temperature of the springs varies between $14-60^{\circ} \mathrm{C}$, thus in some areas the water emerges from $2.5-3 \mathrm{~km}$ depth.

The thermal energy output of the springs is calculated from the outflow rate and the temperature:

$E=\left(T_{s p}-T_{0}\right) Q c \rho$

where: $\mathrm{E}$ is the thermal energy output [W], $T_{s p}$ is the temperature of the spring $\left[{ }^{\circ} \mathrm{C}\right], T_{0}$ is the mean annual surface temperature in the mountains $\left[{ }^{\circ} \mathrm{C}\right], Q$ is the outflow rate $\left[\mathrm{m}^{3} / \mathrm{s}\right]$, 


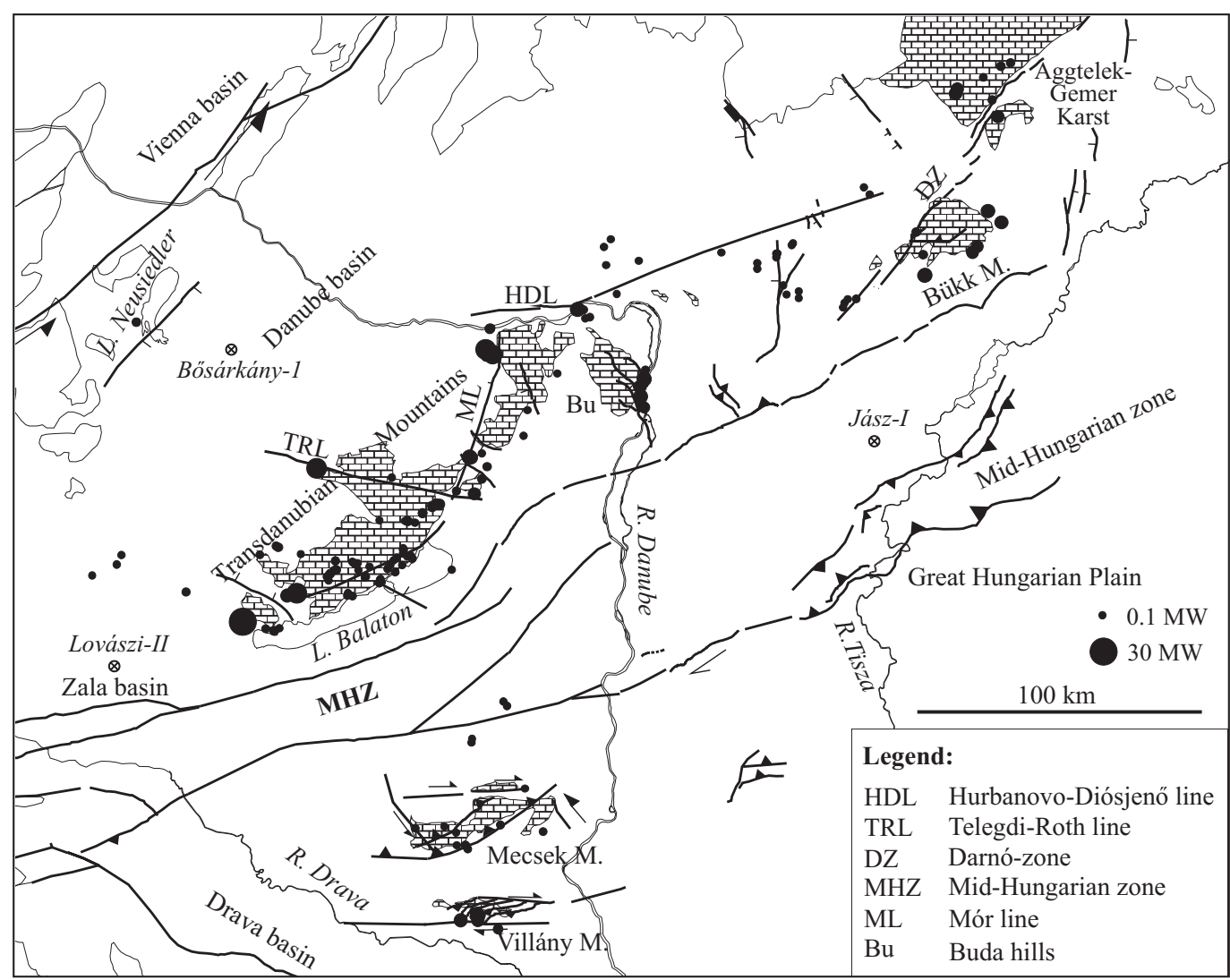

Fig. 2. Natural thermal springs in Hungary (Izápy, 1997), the outcrops of carbonatic rocks and the faults, which were active in the Late Pliocene to present period (after Fodor et al., 1999). Circles are proportional to the thermal energy output of the springs.

Table 1. Correction of the heat flow for advective heat transport by groundwater flow in the karstic areas in Hungary. Advective heat flow component $=$ Total thermal output of springs/Area of the outcrop, Corrected heat flow $=$ Measured heat flow + Advective heat flow component)

\begin{tabular}{lcccc}
\hline & $\begin{array}{c}\text { Total thermal } \\
\text { output of springs } \\
{[\mathrm{MW}]}\end{array}$ & $\begin{array}{c}\text { Area of the } \\
\text { outcrop } \\
{\left[\mathrm{km}^{2}\right]}\end{array}$ & $\begin{array}{c}\text { Advective heat } \\
\text { flow component } \\
{\left[\mathrm{mW} / \mathrm{m}^{2}\right]}\end{array}$ & $\begin{array}{c}\text { Corrected heat } \\
\text { flow } \\
{\left[\mathrm{mW} / \mathrm{m}^{2}\right]}\end{array}$ \\
\hline $\begin{array}{l}\text { Transdanubian } \\
\text { Mountains }\end{array}$ & 3140 & 7200 & 20 & 80 \\
$\begin{array}{l}\text { Mecsek-Villány } \\
\text { Mountains }\end{array}$ & 17 & 1100 & 115 & 105 \\
Bükk Mountains & 26 & 750 & 35 & 105 \\
\hline
\end{tabular}

$c$ is the heat capacity of water $\left[\mathrm{Jkg}^{-1}{ }^{\circ} \mathrm{C}^{-1}\right]$ and $\rho$ is the density of water $\left[\mathrm{kg} / \mathrm{m}^{3}\right]$.

The total thermal energy output of the thermal springs in the Transdanubian, Mecsek-Villány, and Bükk Mountains is shown in Table 1. The ratio of the total energy output and the area of the mountains gives an estimate of the convective heat flow component caused by the groundwater flow. Adding this value to the observed heat flow we obtain the "undisturbed" heat flow of the mountains (Table 1). The heat flow corrected for groundwater flow is close to the heat flow observed around the mountains.
Most of the thermal springs are found at the feet of the mountains. Their location is probably determined by faults, along which the thermal water can emerge from depth. The mean annual surface temperature in Hungary is $12^{\circ} \mathrm{C}$ (Dövényi et al., 1983). Fig. 2 displays the location of the springs in Hungary, which have temperature higher than $12^{\circ} \mathrm{C}$, and faults, which were active during the Late Pliocene to present period. The springs are classified according to their thermal energy output. The springs which are not associated with karstic water flow systems have negligible thermal energy output. Almost half of the springs emerge along 


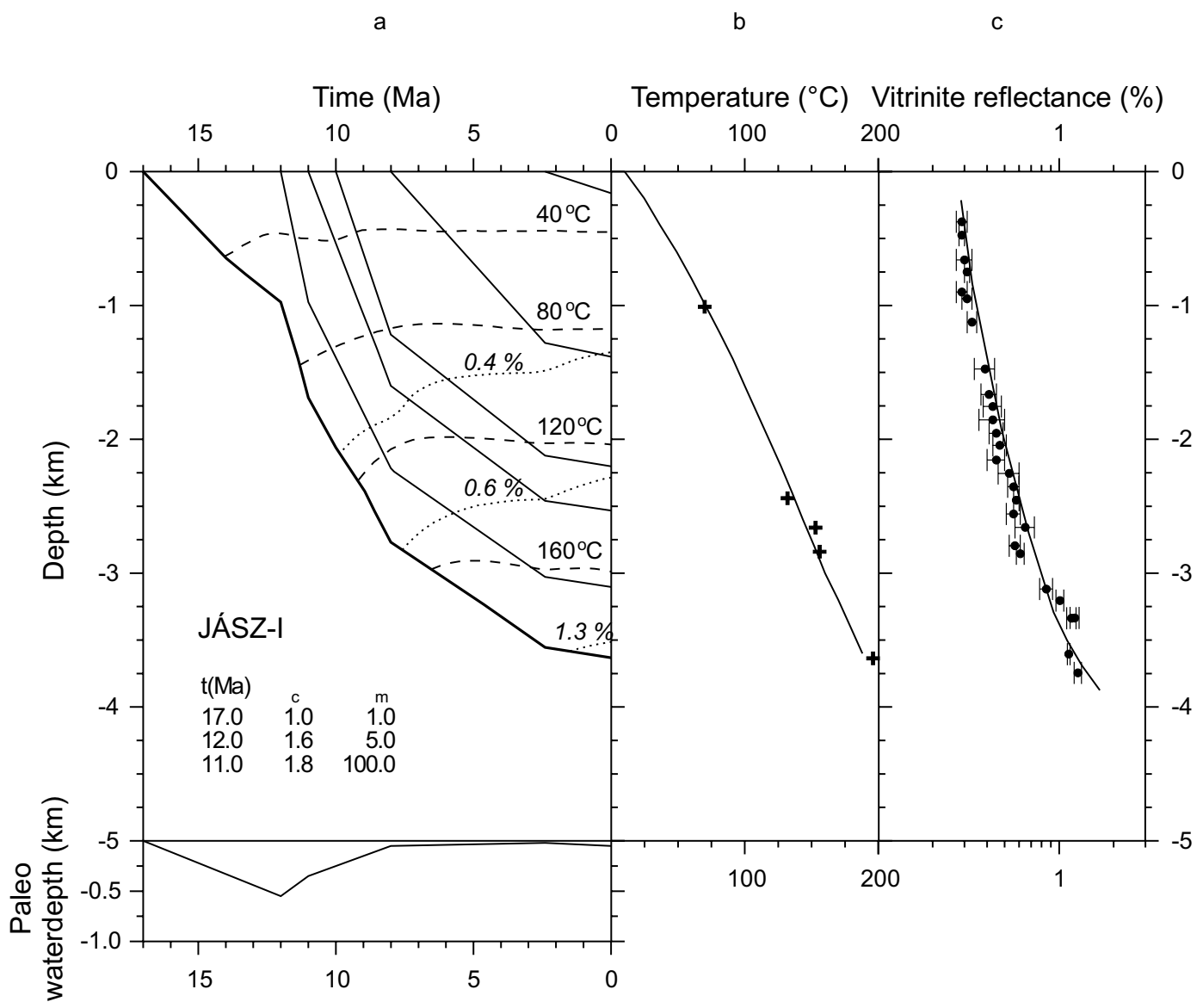

Fig. 3. Sediment accumulation, thermal and maturation history model of the Jász-I well. (a) Continuous, dashed and dotted lines show the evolution of the thickness of sediments, temperature and vitrinite reflectance through time, respectively. $\beta \mathrm{c}$ and $\beta \mathrm{m}$ is the crustal and mantle thinning factor, respectively, which result in fit to the sediment accumulation history, the present day observed temperatures and vitrinite reflectances. Negative paleowaterdepth values indicate waterdepth, positive values mean elevation above sea level. (b) Present day temperature. Crosses denote the measured temperature, continuous line denotes the modelled temperature. (c) Present day vitrinite reflectance. Dots with error bars indicate the measured, continuous line denotes the modelled vitrinite reflectances.

faults, which are presently active or were active in the Late Pliocene-Quaternary time. All springs in the Villány hills and except one spring in the Mecsek Mountains are associated with young faults. The most important active faults (TRL, ML, HDL and DZ) are accompanied by springs. The most impressive coincidence of a line of springs with a Quaternary fault exists in the Buda hills, where the springs clearly indicate the eastern border fault of the hills.

\section{Geothermics and vertical movements in the Pannon- ian basin}

The present-day high heat flow in the Pannonian basin and the formation of the basin can be explained by depthdependent extension of the lithosphere, which occurred during Early to Middle Miocene time (Royden et al., 1983; Royden and Dövényi, 1988; Lankreijer et al., 1995; Sachsenhofer et al., 1997, Lenkey, 1999). Horváth et al. (1988) modified the depth-dependent extensional model of Royden and Keen (1980) by taking into consideration the heat generation in the crust and the thermal effect of sedimentation including the compaction of sediments, and calculated the subsidence, thermal and maturation history of sediments in the Great Hungarian Plain. The subsidence and thermal history were derived from the amount of thinning of the crust $(\beta \mathrm{c})$ and the mantle part of the lithosphere $(\beta \mathrm{m})$, and the thermal maturation of organic matter were calculated by the use of the time-temperature index (TTI, Waples, 1980). TTI was converted to vitrinite reflectance using an empirical relationship between the TTI and the vitrinite reflectances measured in master wells from the Great Hungarian Plain (Horváth et al., 1988).

The subsidence, thermal and maturation history of the Jász-I well is shown in Fig. 3 as an example. The well is located in the Great Hungarian Plain (for location see Fig. 2), and penetrated the Paleozoic basement at a depth of $3637 \mathrm{~m}$. The thick line starting from the surface at $17 \mathrm{Ma}$ and reaching $3637 \mathrm{~m}$ at the present shows the accumulation of the Neogene and Quaternary sediments. The other lines starting from the surface from left to right show the thicknesses of progres- 


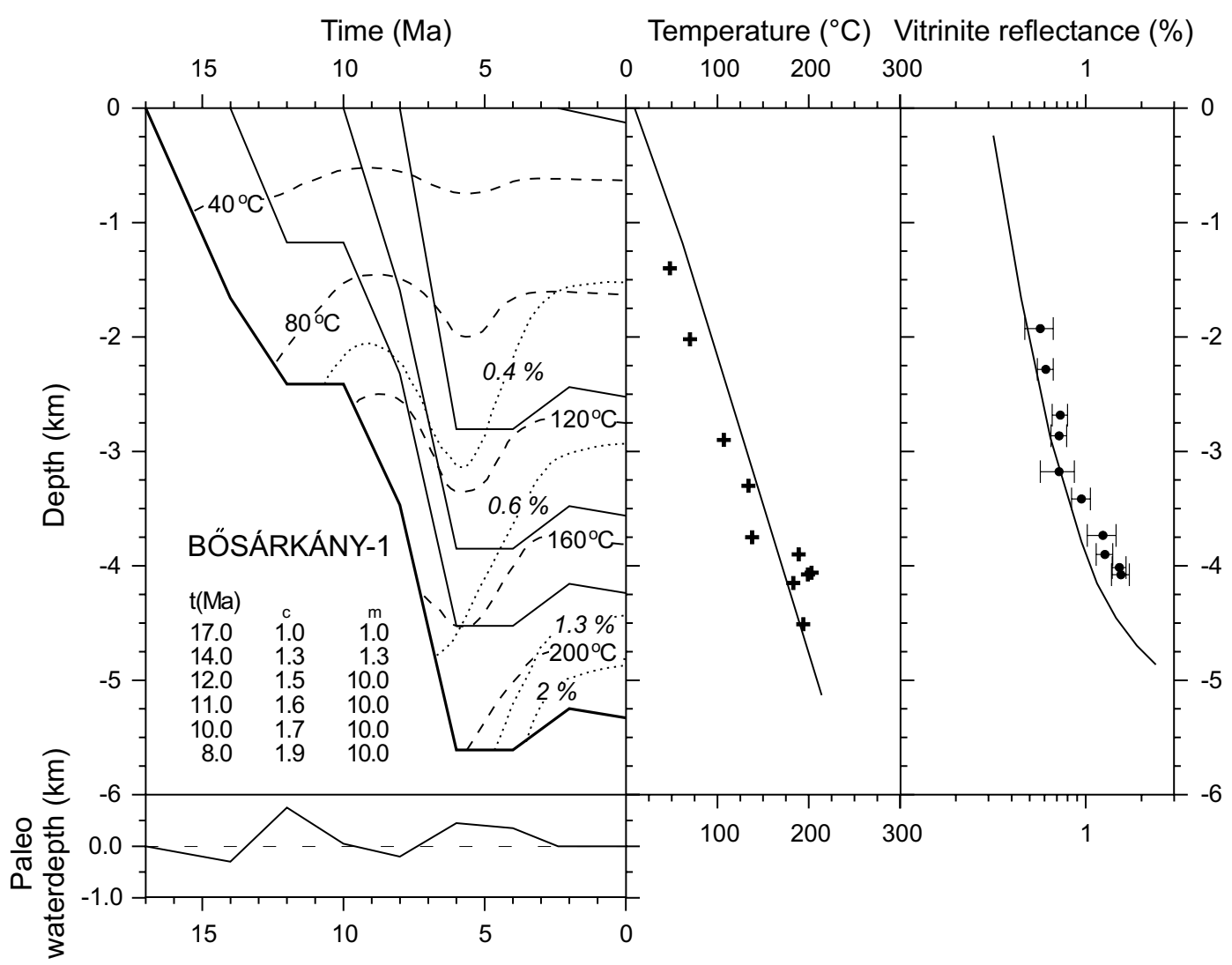

Fig. 4. (a) Sediment accumulation, thermal and maturation history model of the Bôsárkány-1 well. Note the Late Pliocene uplift and erosion. (b) Present day measured and modelled temperature. (c) Present day measured and modelled vitrinite reflectance. For detailed description see Fig. 3.

sively younger sediments. The water depth was calculated as the difference between the predicted basement depth and the thickness of sediments. The subsidence rate in the first $5 \mathrm{Ma}$ was higher than the sediment accumulation rate resulting in relatively deep water. This is in agreement with the sedimentological observations (Juhász, 1994) and interpretation of seismic sections (Vakarcs et al., 1994), which show that the basin was filled up by a delta system prograding into the basin from the peripheral areas. The dashed and dotted lines indicate the evolution of temperature and vitrinite reflectance through time, respectively. The temperature-depth and vitrinite reflectance-depth profiles calculated for the present are in good agreement with the observations. The best fit thermal and vitrinite reflectance model of the Jász-I well is obtained assuming that the lithospheric extension started at $17 \mathrm{Ma}$ and lasted till $11 \mathrm{Ma}$ and it caused thinning of the crust and the mantle lithosphere by a factor of $1.8(\beta \mathrm{c})$ and $100(\beta \mathrm{m})$, respectively. Since $11 \mathrm{Ma}$ cooling of the lithosphere occurs causing thermal subsidence.

Similar studies were performed in many wells in different parts of the Pannonian basin as the calculation of the thermal maturity became a common tool in the oil industry. Wells from the Great Hungarian Plain exhibit very sim- ilar subsidence, thermal and maturation history as the Jász-I well. However, wells from the Danube basin and some wells from the Zala basin have different subsidence and thermal history. The observed vitrinite reflectance in these wells is higher and the trend is parallel to the vitrinite reflectance calculated by a simple subsidence and burial model. To obtain fit to the observed virinite reflectance in the Bôsárkány-1 (Fig. 4) and the Lovászi-II (Fig. 5) wells (for location see Fig. 2) additional burial had to be assumed during the Late Miocene-Early Pliocene, which was followed by erosion during the Late Pliocene-Quaternary. (If higher heat flow were assumed in the past without erosion, then the observed and calculated vitrinite reflectance trends would not be parallel.) The amount of the eroded sediments is about $400 \mathrm{~m}$. In case of the Lovászi-II well part of the uplift comes from the inversion of the basin structure as shown by seismic sections (Rumpler and Horváth, 1988).

Late Pliocene-Quaternary uplift and erosion is a common phenomena in the peripheral subbasins of the Pannonian basin. Based on vitrinite reflectance modelling Francu et al. (1989) concluded that about $750 \mathrm{~m}$ erosion occurred in the East Slovakian basin during the Late Miocene and Pliocene. Subsidence analysis of wells from the 


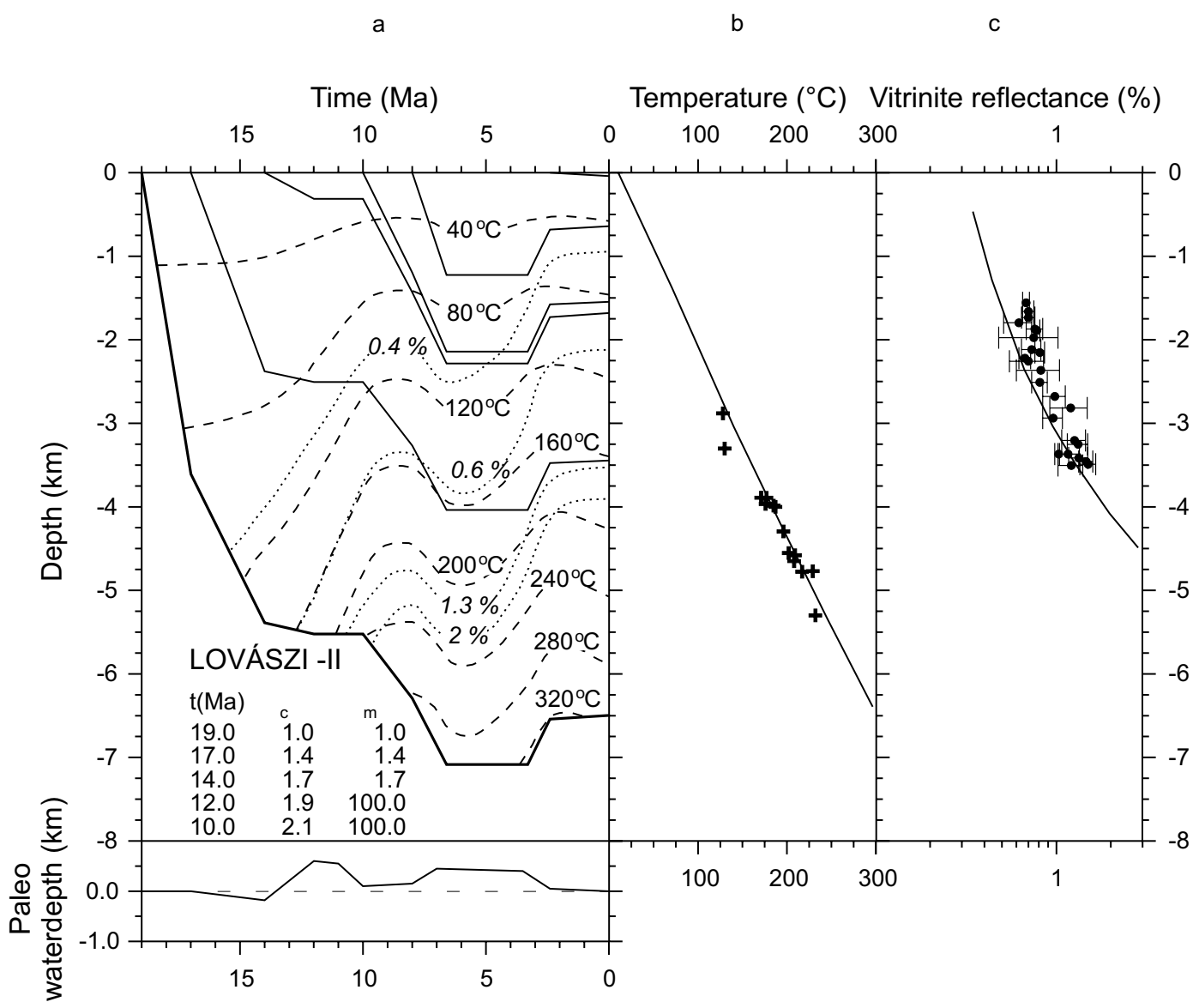

Fig. 5. (a) Sediment accumulation, thermal and maturation history model of the Lovászi-II well. Note the Late Pliocene uplift and erosion. (b) Present day measured and modelled temperature. (c) Present day measured and modelled vitrinite reflectance. For detailed description see Fig. 3.

Styrian basin (Sachsenhofer et al., 1997) and vitrinite reflectance modelling (Sachsenhofer et al., 2001) revealed Late Pliocene-Quaternary uplift and tilt of the Styrian basin towards the Pannonian basin. The amount of erosion is in the range of $300-500 \mathrm{~m}$.

The subsidence, thermal and maturation studies in the Pannonian basin show that following rifting thermal subsidence occurred, which is still going on in the deepest parts of the basin. However, in the peripheral parts of the basin the subsidence was interrupted by uplift and erosion. This uplift cannot be explained by the extensional model. The Late Pliocene and Quaternary inversion of the thermal subsidence is one of the most important phenomena, which indicates that the tectonic regime in the Pannonian basin has changed and the extensional evolution of the basin has terminated.

Cloetingh et al. $(1985,1989)$ have put forward the idea that compressive intraplate forces originating from processes operating at plate boundaries cause large scale bending and folding of the lithosphere. The surface expression of this process is differential uplift and subsidence of up to several hundreds meter. The present day stress field in the Pannonian basin is compressive and transpressive (Gerner et al., 1999; Bada et al., 1999). The transition from transtensive or neutral stress field to compressive stress field might have occurred in Late Pliocene/Quaternary time, when the uplift began. Horváth and Cloetingh (1996) and van Balen et al. (1999) modelled the late stage uplift along 2D sections crossing the Pannonian basin assuming compressive intraplate stress and arrived at the conclusion that an increase in the level of stress explains the few hundred meter uplift.

\section{Geothermics and seismicity}

The Pannonian basin is characterized by low to moderate seismic activity (Gerner et al., 1999; Tóth et al., this issue). In contrast, the Dinarides and the Vrancea zone are seismically more active areas. Table 2 lists the different tectonic units of the area according to their seismicity and heat flow. It is clear that the geothermal conditions strongly influence the seismicity. High seismicity concentrates in those areas where low heat flow values pertain, and the areas characterized by high heat flow have low to moderate seismicity. The areas surrounding the Pannonian basin from north and east are characterized by low heat flow and low seismicity, but these areas comprise a different tectonic realm. Stress obser- 
a

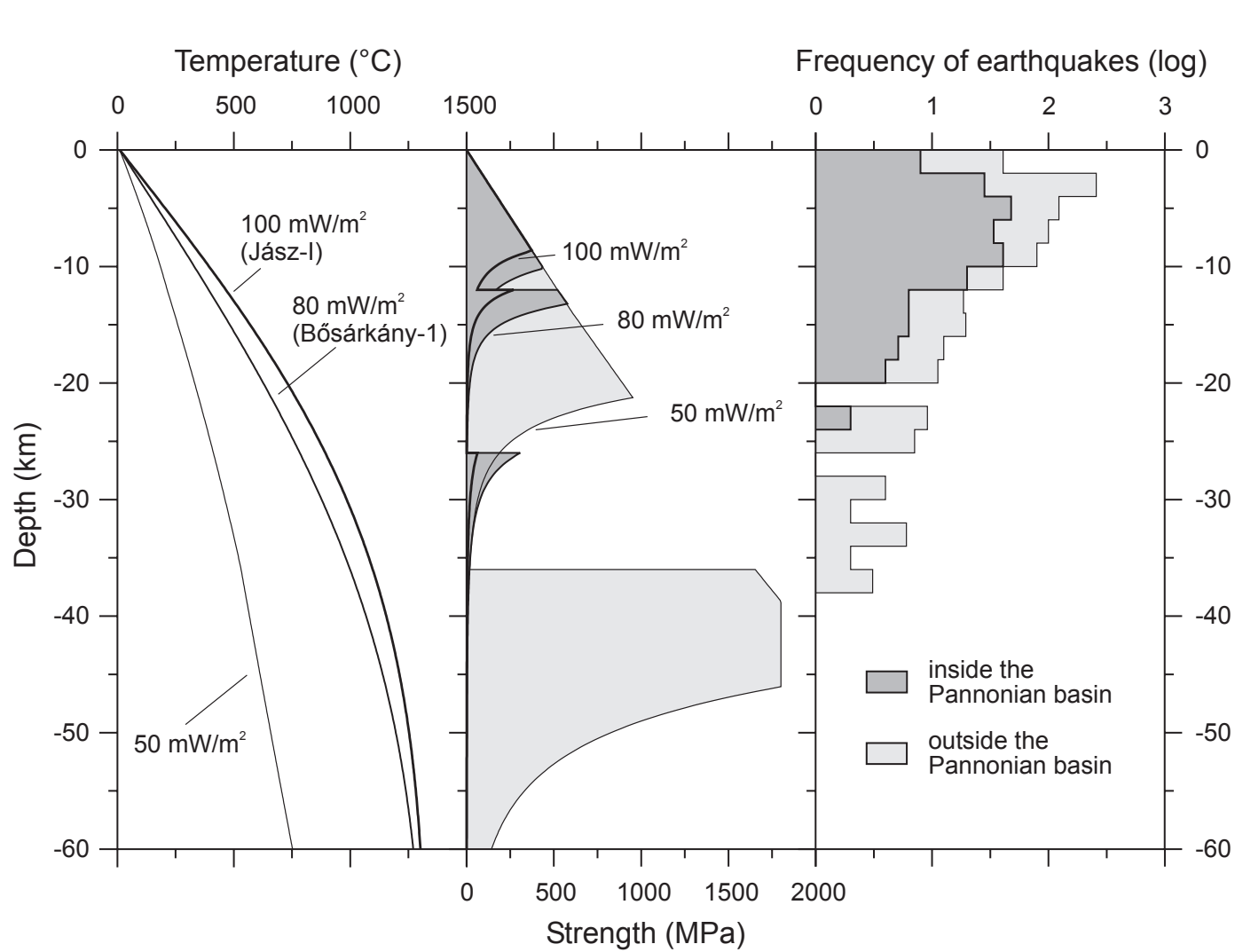

Fig. 6. (a) Lithospheric temperature profiles, (b) rheological profiles according to the geotherms and (c) the distribution of the focal depth of earthquakes in the Pannonian basin and the surrounding region (after Zsíros et al., 1989). Lithospheric temperature for the geotherms with 80 and $100 \mathrm{~mW} / \mathrm{m}^{2}$ is derived from the extensional model of the Bósárkány-1 and Jász-I wells, respectively. The geotherm with $50 \mathrm{~mW} / \mathrm{m}^{2}$ is calculated from a steady-state conduction model. See the explanation of the calculation of the rheological profiles in the text.

Table 2. Comparison between the seismicity of tectonic units and their heat flow in the Carpathian-Pannonian-Dinaric region

\begin{tabular}{lccc}
\hline & Low seismicity & Moderate seismicity & High seismicity \\
\hline Normal heat flow & $\begin{array}{c}\text { Bohemian Massif } \\
\text { European Plate } \\
\text { Ukrainian Shield } \\
\text { Moesian Platform }\end{array}$ & Vienna basin & Dinarides \\
Vrancea zone & & \\
High heat flow & $\begin{array}{c}\text { Pannonian basin } \\
\text { in general }\end{array}$ & $\begin{array}{c}\text { Transcarpathian depression } \\
\text { northern part of the Sava } \\
\text { trough }\end{array}$ & - \\
\hline
\end{tabular}

vations, seismicity studies and stress modelling show that the recent tectonic activity of the Pannonian region is controlled primarily by the counterclockwise rotation of the Adriatic microplate (Bada et al., 1999). As a result, the Pannonian basin is pushed from the south-southwest. The low seismicity of the surrounding area indicates that most of the energy supplied by the relative motion of the Adriatic plate is consumed by the Dinarides and the Pannonian basin. The Bohemian Massif, Ukrainian and the Moesian Platforms form a cold, rigid frame of the basin system comprising a separate tectonic realm. In the Pannonian-Dinaric tectonic realm the heat flow (lithospheric temperature) is one of the most important factors controlling the seismicity (Table 2). However, as shown by the moderate seismicity of some "hot" areas, the temperature structure in the lithosphere is an important, but not necessarily the only one controlling factor in determining the seismicity. The areas characterized by moderate to high seismicity are located in the peripheral parts of the basin, particularly in the Dinarides, where different thermal regimes and tectonic units are in contact with each other.

The geothermal conditions control the seismicity through the rheology of the lithosphere. Beside the temperature the 
Table 3. Thermal parameters of the temperature-depth profile of the standard lithosphere (geotherm with $50 \mathrm{~mW} / \mathrm{m}^{2}$ in Fig. $6 \mathrm{a}$.) and material properties used for the rheological profiles in Fig. 6b. Thermal parameters are after Kappelmeyer and Haenel (1974) and Zoth and Haenel (1988). Boundary conditions for the temperature calculation: top $(z=0 \mathrm{~km}) T=10^{\circ} \mathrm{C}$, bottom $(z=120 \mathrm{~km}) T=1333^{\circ} \mathrm{C}$. The thermal conductivity is measured on $20^{\circ} \mathrm{C}$ and it depends on the temperature according to Sekiguchi (1984). Material properties are after Carter and Tsenn (1987) and Goetze and Evans (1979). $g$ is the gravity acceleration $\left[9.81 \mathrm{~m} / \mathrm{s}^{2}\right], R$ is the universal gas constant $\left[8.314 \mathrm{JmolK}^{-1}\right]$ and $\varepsilon$ is the strain rate, accepted value is $10^{-15} \mathrm{~s}^{-1}$.

\begin{tabular}{|c|c|c|c|}
\hline & Upper crust & Lower Crust & Mantle \\
\hline \multicolumn{4}{|c|}{ Thermal parameters } \\
\hline thermal conductivity $\left[\mathrm{Wm}^{-1} \mathrm{~K}^{-1}\right]$ & 3 & 2.3 & 4 \\
\hline heat production $\left[\mu \mathrm{Wm}^{-3}\right]$ & 1.5 & 0.5 & 0.01 \\
\hline \multicolumn{4}{|c|}{ Rheological parameters } \\
\hline \multicolumn{4}{|l|}{ Brittle domain, Byerlee's law $\sigma=\alpha \rho g(1-\tau)$} \\
\hline $\begin{array}{l}\text { slope of the pressure branch for } \\
\text { compression }(\alpha)\end{array}$ & & 1.67 & \\
\hline pore fluid factor $(\tau)$ & & 0.35 & \\
\hline density $(\rho)\left[\mathrm{kgm}^{-3}\right]$ & 2650 & 2900 & 3300 \\
\hline \multicolumn{4}{|c|}{ Power law domain, Creep function $\sigma=(\varepsilon / A)^{1 / n} \exp [E /(n R T)]$} \\
\hline type of rock & dry granite & dry diabase & dry dunite \\
\hline power law exponent $(n)$ & 3.3 & 3.05 & 4.5 \\
\hline power law activation energy $(E)\left[\mathrm{kJmol}^{-1}\right]$ & 186 & 276 & 535 \\
\hline pre-exponential constant $(A)\left[\mathrm{Pa}^{-n} \mathrm{~s}^{-1}\right]$ & $3.16 \times 10^{-26}$ & $6.31 \times 10^{-20}$ & $7.94 \times 10^{-18}$ \\
\hline
\end{tabular}

rheology depends on the lithospheric material, its flow properties and the strain-rate. Fig. 6 shows temperature-depth and rheological profiles characteristic for the Pannonian basin and the surrounding region. The lithospheric temperature in the Pannonian basin is not steady-state, therefore, the conventional thermal models assuming steady-state to calculate the lithospheric temperature from the surface heat flow and radiogenic heat production in the crust and mantle cannot be used. The temperature-depth profiles resulting from the subsidence and thermal history modelling of the Jász-I and Bôsárkány-1 wells were used in the calculation of the rheological profiles. The heat flow in the surrounding areas of the Pannonian basin is in the range of $50-60 \mathrm{~mW} / \mathrm{m}^{2}$, (in the Dinarides it is even lower, $30-50 \mathrm{~mW} / \mathrm{m}^{2}$ ). For representing the surrounding areas a synthetic temperature-depth profile was calculated in the conventional way, by solving the heat conduction equation in one-dimension assuming steady-state thermal regime and surface heat flow of $50 \mathrm{~mW} / \mathrm{m}^{2}$. It was assumed that the thermal conductivity of rocks depends on the temperature according to Sekiguchi (1984). The thermal parameters of the lithosphere are shown in Table 3.

The lithospheric strength in the brittle regime was calculated by a modified version of the Byerlee's law (Byerlee, 1978; Ranalli and Murphy, 1987), in the ductile regime by power-law creep (Goetze and Evans, 1979; Carter and Tsenn, 1987). The stress field in the Pannonian region is compressive, therefore the criteria of brittle failure is calculated for thrust faulting. A three layer lithosphere was assumed, where the upper crust, lower crust and mantle consisted of dry granite, dry diorite and dry dunite, respectively. For simplicity the sediments were replaced by dry granite. The rheological properties of rocks are shown in Table 3. For the crustal thickness in the Pannonian basin and the surrounding region $26 \mathrm{~km}$ and $36 \mathrm{~km}$ was adopted, respectively. The strain-rate was assumed to be $10^{-15} \mathrm{~s}^{-1}$.

According to the rheological profiles the brittle crustal layer in the Pannonian basin is less than $14 \mathrm{~km}$ due to the high temperature in the lithosphere. The brittle upper crustal layer is underlain by a ductile lower crust and mantle. In those areas where the heat flow is higher than $100 \mathrm{~mW} / \mathrm{m}^{2}$ the strength of the lithosphere is reduced to the upper $10 \mathrm{~km}$ thick brittle part of the crust, because the strength of the lower crust is highly reduced and the mantle has no strength. The decrease of the lithospheric temperature and surface heat flow results in strengthening of the lithosphere. When the surface heat flow is $50 \mathrm{~mW} / \mathrm{m}^{2}$ the upper part of the lower crust becomes brittle and the thickness of the brittle layer increases to $20-24 \mathrm{~km}$. A $10 \mathrm{~km}$ thick brittle layer appears in the upper mantle, too.

The increase of the thickness of the brittle layer with decreasing heat flow is supported by the distribution of the focal depth of earthquakes (Fig. 6). Earthquakes inside the Pannonain basin occur down to depth $20 \mathrm{~km}$, with maximum number of earthquakes concentrating in the depth range of 
$6-10 \mathrm{~km}$. There is a sharp decrease in the number of earthquakes below $12 \mathrm{~km}$. The scarcity of earthquakes in the lower crust and the lack of earthquakes below $20 \mathrm{~km}$ indicates that in this layer the dominant mode of deformation is ductile flow. The relaxation of the tectonic stress by ductile flow results in decrease of the seismicity in the Pannonian basin. Earthquakes in the surrounding areas also concentrate in the upper $10 \mathrm{~km}$ part of the crust, but there are earthquakes down to depth $40 \mathrm{~km}$. The presence of deeper focal depths indicates that in the surrounding areas the thickness of the brittle layer higher than inside the basin. Earthquakes below $30 \mathrm{~km}$ depth may occur either in the lower crust or in the upper mantle. From the statistics of the focal depth distribution of Fig. 6 alone it is not possible to discriminate between the two scenarios. Thick crust and low heat flow (characteristics of the Eastern and Southern Carpathian foredeep) or the brittle layer in the upper mantle can explain the relatively deep earthquakes foci.

The rheological model in Fig. 6 cannot explain the occurrence of medium depth earthquakes $(80-180 \mathrm{~km})$ in the Vrancea zone. The earthquakes are most probably generated by a subducted lithospheric slab. A gap in the earthquake foci between $30-70 \mathrm{~km}$ depth may indicate that the slab detached from the European lithosphere and descends into the asthenosphere (Wenzel et al., 1998).

\section{Conclusions}

1) The distribution of seismicity in the Pannonian region can be interpreted in terms of tectonic realms and heat flow. The tectonically less active Bohemian Massif, Ukrainian Shield and Moesian Platform form a cold rigid frame of the Pannonian basin. The Pannonian basin and the Dinarides comprise a seismotectonic realm, where the seismicity in general is controlled by the thermal conditions of the lithosphere. Low and moderate seismicity occurs in areas of high heat flow (>90 $\mathrm{mW} / \mathrm{m}^{2}$, in the Pannonian basin), high seismicity is characteristic for areas of normal to low heat flow $\left(<60 \mathrm{~mW} / \mathrm{m}^{2}\right.$, in the Dinarides $)$.

2) In the Pannonian basin shallow earthquakes occur, while in the surrounding areas the focal depth increases. This observation is in agreement with the predicted strength variation of the lithosphere, which show that the thickness of the brittle layer increases from 10$14 \mathrm{~km}$ in the Pannonian basin to $20-25 \mathrm{~km}$ in the surrounding areas. In the areas of low heat flow a brittle layer in the upper mantle can account for the relatively deep $(>30 \mathrm{~km})$ earthquakes.

3) Thermal and maturation history modelling results in a better understanding of the present day thermal conditions and tectonic processes. Modelling of vitrinite reflectance shows that the thermal cooling phase of basin evolution and subsidence in the peripheral parts of the
Pannonian basin has terminated in the Late Pliocene and since that time uplift is going on.

4) Thermal springs are good indicators of deep-rooted faults. However, it requires structural and seismological studies to decide, whether the fault is active or it is an older fault. Almost half of the thermal springs in Hungary arise along faults, which were active during the Late Pliocene to recent period.

Acknowledgements. We are grateful to Fred Beekman who provided the software "Yield" to calculate the rheological profiles. Comments from E. Burov and V. Čermak were very much appreciated. L. Lenkey thanks the financial support given by the János Bolyai Research Grant.

\section{References}

Babuška, V. and Plomerová, J.: Subcrustal continental lithosphere: a model of its thickness and anisotropic structure, Phys. Earth Planet. Inter., 51, 130-132, 1988.

Bada, G., Horváth, F., Gerner, P., and Fejes, I.: Review of the present-day geodynamics of the Pannonian basin: progress and problems, J. Geodyn., 27, 501-527, 1999.

Bodri, B. and Iizuka, S.: Thermal regime, rheology and seismicity in Central Japan, Tectonophysics, 217, 1-9, 1993.

Bullard, E. C.: Heat flow in South Africa, Proc. Roy. Soc. London, Ser. A., 173, 474-502, 1939.

Byerlee, J. D.: Friction of rocks, Pure and Applied Geophysics, 116, 615-626, 1978.

Carter, N. L. and Tsenn, M. C.: Flow properties of continental lithosphere, Tectonophysics, 136, 27-63, 1987.

Čermák, V.: First heat flow map of Czechoslovakia, Trav. Inst. Géophys. Acad. Tchéc. Sci., 461, 245-261, 1978.

Chapman, D. S. and Rybach, L.: Heat flow anomalies and their interpretation, J. Geodyn., 4, 3-37, 1985.

Cloetingh, S. A.P.L., McQuenn, H., and Lambeck, K.: On a tectonic mechanism for regional sea level variations, Earth Planet. Sci. Lett., 75, 157-166, 1985.

Cloetingh, S. A.P.L., Kooi, H., and Groenewoud, W.: Intraplate stress and sedimentary basin evolution, Geophys. Monogr. Am. Geoph. Union, 48, 1-16, 1989.

Demetrescu, C.: On the geothermal regime of some tectonic units in Romania, Pure Appl. Geophys., 117, 124-134, 1978.

Demetrescu, C., Ene, M., Andreescu, M., and Burst, D.: On the geothermal regime of the Moesian Platform and Getic depression, Tectonophysics, 164, 281-287, 1989.

Dövényi, P., Horváth, F., Liebe, P., Gálfi, J., and Erki, I.: Geothermal conditions of Hungary, Geophys. Transactions, 29/1, 3-114, 1983.

Dövényi, P. and Horváth, F.: A review of temperature, thermal conductivity, and heat flow data from the Pannonian Basin, in: Royden, L. H. and Horváth, F. (Eds.): The Pannonian Basin, a Study in Basin Evolution, Amer. Assoc. Petr. Geol. Mem., 45, 195-233, 1988.

Dövényi, P.: Geophysical investigations of the lithosphere of the Pannonian basin, PhD Thesis, Eötvös Univ., Budapest, 127pp, 1994.

Fodor, L., Csontos, L., Bada, G., Györfi, I., and Benkovics, L.: Tertiary tectonic evolution of the Pannonian Basin system and neighbouring orogens: a new synthesis of palaeostress data, in: 
Durand, B., Jolivet, L., Horváth, F., and Séranne, M. (Eds.): The Mediterranean Basins: Tertiary Extension within the Alpine Orogen, Geological Society Special Publication, London, No. 156, 295-334, 1999.

Fowler, C. M. R. and Nisbet, E. G.: The thermal background to metamorphism II. Simple two-dimensional conductive models, Geosci. Canada, 9, 208-214, 1982.

Francu, J., Rudinec, R., and Šimánek, V.: Hydrocarbon generation zone in the East Slovakian Neogene basin: Model and geochemical evidence, Geol. Zborn., Geol. Carp., 40 (3), 355-384, 1989.

Furlong, K. P. and Atkinson, S. M.: Seismicity and thermal structure along the northern San Andreas Fault system, California, USA, Tectonophysics, 217, 23-30, 1993.

Gerner, P., Bada, G., Dövényi, P., Müller, B., Oncescu, M. C., and Cloetingh, S. A. P. L.: Recent tectonic stress and crustal deformation in and around the Pannonian basin: data and models, in: Durand, B., Jolivet, L., Horváth, F. and Séranne, M. (Eds.): The Mediterranean Basins: Tertiary Extension within the Alpine Orogen, Geological Society Special Publication, London, 156, 269294, 1999.

Goetze, C. and Evans, B.: Stress and temperature in the bending lithosphere as constrained by experimental rock mechanics, Geoph. J. Roy. Astr. Soc., 59, 463-478, 1979.

Gordienko, V. V., Gordienko, I. V., Zavgorodnjaja, O. V., and Usenko, O. V.: Heat flow map of Ukraine and Moldova, in: Gordienko, V. V. and Tarasov, V. N. (Eds.): Recent activization and He-isotopy of Ukrainian territory, (in Russian), Znanie, Kiev, p12, 2001.

Horváth, F., Dövényi, P., and Laczó, I.: Geothermal effects of magmatism and its contribution to the maturation of organic matter in sedimentary basins, in: Lecture Notes in Earth Sciences, Vol. 5, Buntebarth, G. and Stegena, L. eds., Paleogeothermics: Springer-Verlag, Berlin/Heidelberg, 173-183, 1986.

Horváth, F., Dövényi, P., Szalay, Á., and Royden, L. H.: Subsidence, thermal and maturation history of the Great Hungarian Plain, in: Royden, L. H. and Horváth, F. (Eds.): The Pannonian Basin, a Study in Basin Evolution, Amer. Assoc. Petr. Geol. Mem., 45, 355-372, 1988.

Horváth, F.: Towards a mechanical model for the formation of the Pannonian basin, Tectonophysics, 226, 333-357, 1993.

Horváth, F. and Cloetingh, S. A. P. L.: Stress-induced late-stage subsidence anomalies in the Pannonian basin, Tectonophysics, 266, 287-300, 1996.

Hurtig, E., Čermák, V., Haenel, R., and Zui, V. I. (Eds.): Geothermal Atlas of Europe, Haack, Gotha, 1992.

Izápy, G. (Ed.): Magyarország forrásainak katasztere, OVFVITUKI, Institute of Hydrology, Budapest, (Database of springs in Hungary), 1997.

Juhász, Gy.: Comparison of the sedimentary sequences in Late Neogene subbasins in the Pannonian Basin, Hungary, Földt. Közl., 124, 341-365, 1994.

Kappelmeyer, O. and Haenel, R.: Geothermics with special reference to application, Geoexploration Monographs, Series 1, Gebrüder Borntraeger, Berlin, Stuttgart, 4, 238pp, 1974.

Kázmér, M., Lenkey, L., Dunkl, I., and Frisch, W.: Why is the Transylvanian Basin is cold? Middle Miocene geodynamics of the Carpathian-Pannonian region, PANCARDI 2000, Dubrovnik, Croatia, 1-3.10.2000. Vijesti Hrvatskoga geološkog društva, 37/3, 60-61, 2000.

Lankreijer, A., Kováč, M., Cloetingh, S. A.P.L., Pitonák, P., Hlôška, M., and Biermann, C.: Quantitative subsidence analysis and forward modelling of the Vienna and Danube basins: thin- skinned versus thick-skinned extension, Tectonophysics, 252, 433-451, 1995.

Lenkey, L.: Geothermics of the Pannonian basin and its bearing on the tectonics of basin evolution, $\mathrm{PhD}$ thesis, Vrije Universiteit, Amsterdam, 215pp, 1999.

Lucazeau, F. and Le Douaran, S.: The blanketing effect of sediments in basins formed by extension: a numerical model. Application to the Gulf of Lion and Viking graben, Earth Planet. Sci. Lett., 74, 92-102, 1985.

Mituch, E. and Posgay, K.: Hungary, in: Szénás, Gy., (Ed.): The crustal structure of Central and South-Eastern Europe based on the results of explosion seismology, Spec. Ed. Geophys. Transact., $172 \mathrm{pp}, 1972$.

Mongelli, F., Zito, G., Ciaranfi, N., and Pieri, P.: Interpretation of heat flow density of the Apennine chain, Italy, Tectonopysics, 164, 267-280, 1989.

Pécskay, Z., Lexa, J., Szakács, A., Balogh, K., Seghedi, I., Konecny, V., Kováč, M., Márton, E., Kaliciak M., Széky-Fux, V., Póka, T., Gyarmati, P., Edelstein, O., Rosu, E., and Zec, B.: Space and time distribution of Neogene-Quaternary volcanism in the Carpatho-Pannonian Region, in: Downes, H. and Vaselli, O. (Eds.): Neogene and related magmatism in the CarpathoPannonian Region, Acta Vulcanol., 7, 15-28, 1995.

Pollack, H. N., Hurter, S. J., and Johnson, J. R.: Heat loss from the Earth's interior: analysis of the global data set, Reviews of Geophysics, 31, 267-280, 1993.

Posgay, K., Albu, I., Mayerová, M., Nakládalová, Z., Ibrmajer, I., Bližkovský, M., Aric, K., and Gutdeutsch, R.: Contour map of the Mohorovicic discontinuity beneath Central Europe, Geophysical Transactions, 36/1-2, 7-13, 1991.

Praus, O., Pecova, J., Petr, V., Babuška, V., and Plomerová, J.: Magnetotelluric and seismological determination of lithosphereasthenosphere transition in Central Europe, Phys. Earth Planet. Inter., 60, 212-228, 1990.

Ranalli, G. and Murphy, D. C.: Rheological stratification of the lithosphere, Tectonophysics, 132, 281-295, 1987.

Ravnik, D., Rajver, D., Poljak, M., and Živcic, M.: Overview of the geothermal field of Slovenia in the area between the Alps, the Dinarides and the Pannonian basin, Tectonophysics, 250, 135149, 1995.

Royden, L. H. and Keen, C. E.: Rifting process and thermal evolution of the continental margin of Eastern Canada determined from subsidence curves, Earth and Planet. Sci. Let., 51, 343-361, 1980.

Royden, L. H., Horváth, F., Nagymarosy, A., and Stegena, L.: Evolution of the Pannonian basin system: 2. Subsidence and thermal history, Tectonics, 2, 91-137, 1983.

Royden, L. H. and Dövényi, P.: Variations in extensional styles at depth across the Pannonian basin system, in: Royden, L. H. and Horváth, F. (Eds.): The Pannonian Basin, a Study in Basin Evolution, Amer. Assoc. Petr. Geol. Mem., 45, 235-255, 1988

Rumpler, J. and Horváth, F.: Some representative seismic reflection lines from the Pannonian basin and their structural interpretation, in: Royden, L. H. and Horváth, F. (Eds.): The Pannonian Basin, a Study in Basin Evolution, Amer. Assoc. Petr. Geol. Mem., 45, 153-169, 1988.

Sachsenhofer, R. F., Lankreijer, A., Cloetingh, S. A.P.L., and Ebner, F.: Subsidence analysis and quantitative basin modelling in the Styrian Basin (Pannonian Basin System, Austria), Tectonophysics, 272, 175-196, 1997.

Sachsenhofer, R. F., Jelen, B., Hasenhüttl, C., Dunkl, I., and Rainer, T.: Thermal history of Tertiary basins in Slovenia (Alpine- 
Dinaride-Pannonian junction), Tectonophysics, 334, 77-99, 2001.

Sekiguchi, K.: A method for determining terrestrial heat flow in oil basinal areas, Tectonophysics, 103: 67-79, 1984.

Sibson, R. H.: Fault zone models, heat flow, and the depth distribution of earthquakes in the continental crust of the United States, Bull. Seismol. Soc. Am., 72, 151-163, 1982.

Surányi, G., Kónya, B., and Lenkey, L.: Concentrations of natural radioactive isotopes in Neogene volcanic rocks from the Pannonian basin, EGS 2002, XXVII General Assembly, Nice, France, 21-26 April 2002, SE2.10-1FR5P-022, 2002.

Tari, G., Horváth, F., and Rumpler, J.: Styles of extension in the Pannonian Basin, Tectonophysics, 208, 203-219, 1992.

Tóth, L., Mónus, P., Zsíros, T., and Kiszely, M.: Seismicity in the Pannonian region - Earthquake data, this issue, 2002.

Vakarcs, G., Vail, P. R., Tari, G., Pogácsás, Gy., Mattick, R. E., and Szabó, A.: Third-order Middle Miocene-Early Pliocene depositional sequences in the prograding delta complex of the Pannonian basin, Tectonophysics, 240, 81-106, 1994.

van Balen, R., Lenkey, L., Horváth, F., and Cloetingh, S. A. P. L.:
Two-dimensional modelling of stratigraphy and compactiondriven fluid flow in the Pannonain basin, in: Durand, B., Jolivet, L., Horváth, F., and Séranne, M. (Eds.): The Mediterranean Basins: Tertiary Extension within the Alpine Orogen, Geological Society Special Publication, London, No. 156, 391-414, 1999.

Waples, D. W.: Time and temperature in petroleum formation: application of Lopatin's method to petroleum exploration, Amer. Assoc. Petr. Geol. Bull., 64, 916-926, 1980.

Wenzel, F., Achauer, U., Enescu, D., Kissling, E., Russo, R., Mocanu, V., and Musacchio, G.: Detailed look at final stage of plate break-off is target of study in Romania, EOS, 79 (48), 589-594, 1998

Zoth, G. and Haenel, R.: Appendix, in: Haenel, R., Rybach, L., and Stegena, L. (Eds.): Handbook of terrestrial heat-flow determination with guidelines and recommendations of the International Heat Flow Commission, Kluwer Academic Publishers, Dordrecht, 449-466, 1988.

Zsíros, T., Mónus, P., and Tóth, L.: Focal depth of Hungarian earthquakes, Gerlands Beitr. Geophys. Leipzig, 98, 146-154, 1989. 